\title{
Analisis Perbandingan Respon Dinamis Dari Kendaraan Yang Menggunakan Shock Absorber Hidrolis Dan Yang Menggunakan Sistem Peredam Dual Flywheel
}

\author{
Piendraswarti Soelistyaning Pangastuti dan Harus Laksana Guntur \\ Jurusan Teknik Mesin, Fakultas Teknologi Industri, Institut Teknologi Sepuluh Nopember (ITS) \\ Jl. Arif Rahman Hakim, Surabaya 60111 Indonesia \\ e-mail : haruslg@me.its.ac.id
}

\begin{abstract}
Abstrak - Dalam upaya mendapatkan kenyamanan dan keamanan kendaraan pada mobil MPV berbagai macam teknologi peredam pun dilakukan. Untuk itu dilakukan pemodelan dan analisis untuk Shock absorber Hidrolis dan peredam Dual flywheel untuk melihat besar ketahanan dari masing-masing suspensi dalam menahan getaran. Pada simulasi ini dicari gaya redam terbaik dari masing-masing peredam untuk dimasukkan pada pemodelan seperempat kendaraan. Gaya redam suspensi shock absorber hidrolis nantinya akan menjadi patokan untuk mendapatkan dimensi pada suspensi dual flywheel. Digunakan variasi material pada dual flywheel yaitu cast iron $(\rho=$ $\left.6800 \mathrm{~kg} / \mathrm{m}^{3}\right)$, stainless steel $\left(\rho=7480 \mathrm{~kg} / \mathrm{m}^{3}\right)$, dan bruss casting $(\rho$ $=8400 \mathrm{~kg} / \mathrm{m}^{3}$ ). Dimensi hidrolis yang digunakan untuk diameter silinder sebesar $0.04 \mathrm{~m}$, diameter piston $\operatorname{rod}=0.03 \mathrm{~m}$ diameter oroface ekspansi $=0.0028 \mathrm{~m}$, diameter orifice kompresi $=0.005 \mathrm{~m}$ dengan massa jenis minyak $860 \mathrm{Kg} / \mathrm{m}^{3}$. Dimensi yang digunakan pada suspensi dual flywheel radius pinion yang digunakan $30 \mathrm{~mm}$, radius flywheel $40 \mathrm{~mm}$ dan ketebalan flywheel adalah $30 \mathrm{~mm}$. Input yang diberikan yaitu input bump dengan severity parameter sebesar 1,5,20 dan input sinusoidal dengan variasi frekuensi dari $0,5 \mathrm{~Hz}-2 \mathrm{~Hz}$ dengan amplitudo sebesar $0.02 \mathrm{~m}$ untuk masing-masing input yang digunakan. Dri pemodelan yang dilakukan didapatkan nilai gaya redam maksimum yang dihasilkan shock absorber hidrolis sebesar 1323.22 N dan suspensi dual flywheel adalah 1480.27 N. Dari hasil pemodelan sistem suspensi shock absorber hidrolis dan dual flywheel didapatkan hasil bahwa semakin besar kecepatan kendaraan maka respon dinamis berupa perpindahan, kecepatan dan percepatan juga semakin besar. Dengan membandingkan respon dinamis yang dihasilkan oleh shock absorber hidrolis dan dual flywheel berdasarkan standard ISO 2631 diketahui bahwa pada kecepatan $10-80 \mathrm{~km} / \mathrm{jam}$ suspensi dual flywheel lebih nyaman digunakan oleh penumpang dibandingkan dengan suspensi shock absorber hidrolis. Sedangkan pada kecepatan tinggi yaitu $90-100 \mathrm{~km} / \mathrm{jam}$ suspensi dual flywheel mulai terlihat lebih tidak nyaman dibandingkan dengan suspensi shock absorber hidrolis.
\end{abstract}

Kata kunci : Shock Absorber Hidrolis, Flywheel, Gaya Redam, respon dinamis dan Inerter

\section{PENDAHULUAN}

$\mathrm{P}$

ERKEMBANGAN teknologi otomotif terus mengalami kemajuan yang sangat pesat. Pada tahun 2012 Badan Pusat Statistik mencatat jumlah mobil penumpang atau jenis kendaraan Multi Purpose Vehicle di Indonesia mencapai 10juta kendaraan. Untuk itu jenis mobil MPV ini banyak sekali pengembangan teknologinya. Berbagai macam teknologi pada mobil MPV telah ditemukan dan dikembangkan dalam upaya memberikan kemudahan, kenyamanan dan keamanan dengan mempertimbangkan beberapa aspek termasuk pada sistem suspensi.

Sistem suspensi berfungsi untuk menahan kejutan-kejutan yang ditimbulkan keadaan jalan dan juga meredam getarangetaran yang diakibatkan oleh keadaan permukaan jalanan yang tidak rata, agar tidak berpindah ke badan mobil. Peraturan mengenai tingkat baku getaran pada tingkat internasional tertuang dalam ISO 2631.

Sistem suspensi yang biasa digunakan pada mobil adalah Shock absorber Hidrolis yaitu peredam yang menggunakan fluida untuk mengendalikan gaya redaman. Seiring dengan berkembangnya teknologi ditemukan teknologi-teknologi peredam baru lain sebagai seperti Torsional Vibration Absorber yaitu piringan dengan pegas yang dapat meredam perubahan kecepatan yang drastis dengan memanfaatkan momem inersia dan koefisien redam torsional sehingga putaran poros menjadi lebih halus. Salah satu teknologi Torsional Vibration Absorber adalah mekanisme peredam dual flywheel.

Pada penelitian ini ingin memperlihatkan perbandingan respon dinamis pemakaian peredam berupa shock absorber hidrolis dengan penggunaan mekanisme dual flywheels pada mobil tipe MPV. Oleh karena itu dilakukan analisis dari pemodelan masing-masing sistem suspensi pada seperempat kendaraan untuk mengetahui respon dinamis berupa perpindahan. kecepatan, dan percepatan kemudian akan dibandingkan kenyamanannya sesuai dengan standard ISO 2631.

\section{URAIAN PENELITIAN}

\subsection{Pengertian Suspensi}

Sistem suspensi dirancang agar mampu menahan berat kendaraan (beban statis) dan mampu menyerap beban dinamis. sehingga pada saat kendaraan melaju dalam kecepatan yang tinggi. sistem suspensi yang berfungsi untuk menahan kejutan atau getaran yang terjadi agar tidak berpindah pada bodi [2]. Salah satu komponen suspensi adalah peredam. Alat yang biasanya digunakan sebagai peredam pada suspensi adalah shock absorber. Sistem suspensi hidrolik (hydraulic suspension) menggunakan minyak sebagai fluida kerja pada silinder hidrolik. Sistem suspensi bekerja dalam dua siklus yaitu siklus kompresi dan siklus ekspansi. Siklus kompresi terjadi ketika piston bergerak ke bawah, menekan fluida hidrolik di dalam ruang bawah piston. Sedangkan siklus ekspansi adalah gerakan naik piston yang membuat minyak shock absorber yang sudah berada di atas menjadi tertekan. 


\subsection{Motion of Base}

Getaran dapat diklasifikasikan menjadi:

Free vibration (gambar 1), terjadi ketika sistem mekanik berangkat dengan input awal dan kemudian dibiarkan bergetar bebas.

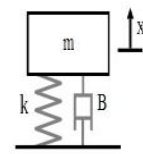

Gambar 1. Contoh sederhana dari sistem free vibrations with damping [11]

Berikut penurunan persamaan dari gambar 1:

$$
m \ddot{x}+B \dot{x}+k x=0
$$

\subsection{Penelitian Terdahulu}

Malcolm C. Smith, dkk [1] dalam penelitiannya pada "Synthesis of Mechanical Networks: The Inerter" membandingkan respon dinamis dari massa yang ditambahkan sistem suspensi inerter dengan massa yang sistem suspensi konvensional.

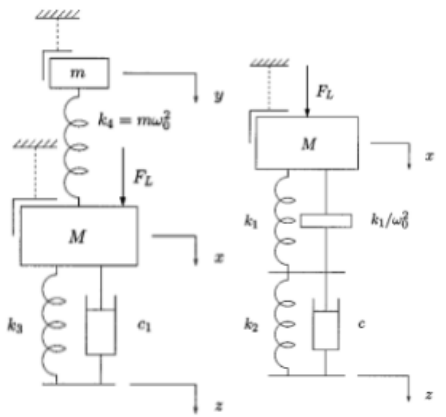

Gambar 2. Massa yang ditambahkan sistem (a) suspensi inerter dan (b) sistem suspensi konvensional [1]

Pada gambar 2 (b) dimana peredam getaran terdiri dari spring-mass yang sistemnya telah terhubung dengan massa $M$.

Berdasarkan pada pembahasan penelitian, disimpulkan bahwa inerter memberikan alternatif untuk mengatasi 9masalah peredaman getaran yang masih konvensional (standar). Hasil respon frekuensi dan respon perpindahan inerter lebih stabil dibandingkan dengan sistem suspensi konvensional, seperti yang terlihat pada grafik gambar 3

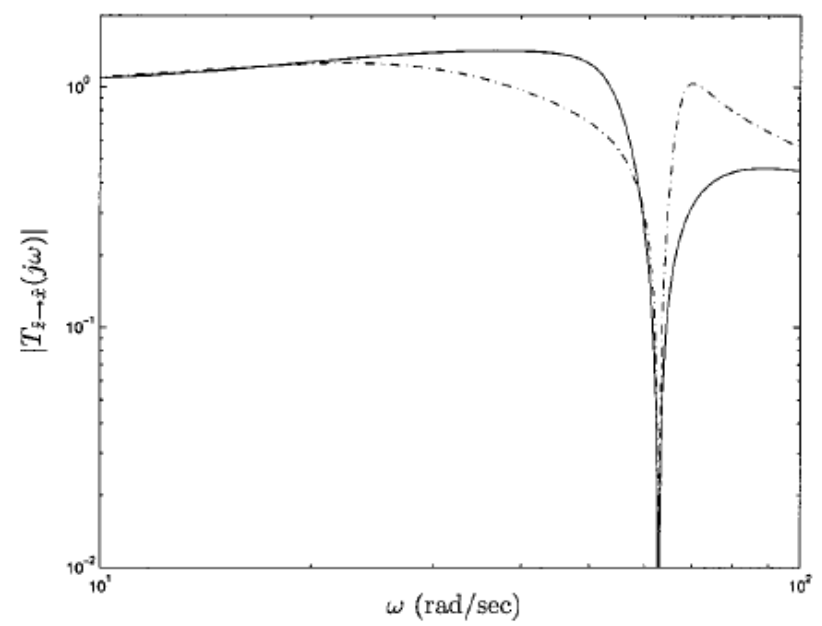

(a)

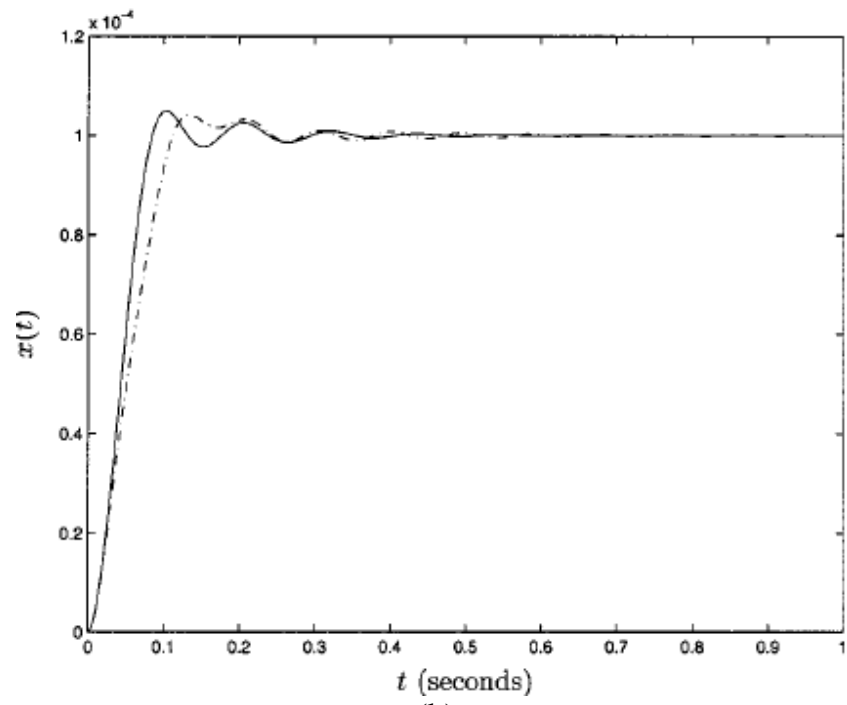

(b)

Gambar 3. Grafik force transmissibility (a) dan grafik respon dinamis perpindahan terhadap waktu (b) pada sistem suspensi inerter (garis putusputus) dan sistem suspensi konvensional (line) [1].

\section{HASIL DAN ANALISA}

3.1 Perumusan Gaya Redam pada Shock Absorber Hidrolis

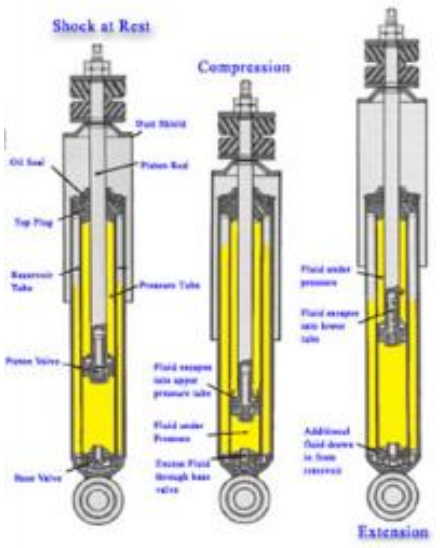

Gambar 4 Gambar fisik Shock Absorber Hidrolis

Tabel 1

Parameter sistem suspensi Hydraulic Shock Absorber

\begin{tabular}{ll}
\hline Parameter & Nilai \\
\hline Diameter silinder hidrolik (Dp) & $0,04 \mathrm{~m}$ \\
Diameter piston road (Dpr) & $0,03 \mathrm{~m}$ \\
Diameter orifice 1 $\left(\mathrm{D}_{\mathrm{e}}\right)$ & $0,0028 \mathrm{~m}$ \\
Diameter orifice 2 $(\mathrm{Dk})$ & $0,005 \mathrm{~m}$ \\
Massa jenis minyak $(\rho)$ & $860 \mathrm{Kg} / \mathrm{m}^{3}$ \\
\hline
\end{tabular}

Perumusan matematis didapatkan dari penurunan rumus Bernoulli dan hukum pascal maka,

$\mathrm{F}_{\mathrm{d}}=\frac{\rho}{2}\left(\left(\frac{\mathrm{A}_{\text {Piston }} \times \mathrm{v}_{\text {Piston }}}{\mathrm{A}_{\text {oriface }}}\right)^{2}-V_{\text {piston }}^{2}\right) \mathrm{A}_{\text {Piston }}$

$\mathrm{F}_{\mathrm{d}}=\frac{\rho}{2} V_{\text {piston }}^{2}\left(\left(\frac{\mathrm{A}_{\text {Piston }}}{\mathrm{A}_{\text {oriface }}}\right)^{2}-1\right) \mathrm{A}_{\text {Piston }}$

a. Ekspansi

Dikarenakan gaya redam dipengaruhi oleh energi disipasi dari minyak maka:

$\mathrm{F}_{\mathrm{d}}=\frac{\rho}{2}\left(\mathrm{~A}_{\text {Piston }}-\mathrm{A}_{\text {Pistonrod }}\right)\left(\left(\frac{\mathrm{A}_{\text {Piston }}-\mathrm{A}_{\text {Pistonrod }}}{\mathrm{A}_{\text {oriface }} \xi}\right)^{2}-1\right)\left(\dot{x_{1}}-\dot{x_{2}}\right)^{2}$

b. Kompresi

$\mathrm{F}_{\mathrm{d}}=\frac{\bar{\rho}}{2}\left(\mathrm{~A}_{\text {Piston }}\right)\left(\left(\frac{\mathrm{A}_{\text {Piston }}}{\mathrm{A}_{\text {oriface }} \xi}\right)^{2}-1\right)\left(\dot{\mathrm{x}}_{1}-\dot{\mathrm{x}_{2}}\right)^{2}$ 
Dimana nilai $p=$ tekanan $v=$ kecepatan, $\mathrm{F}_{\mathrm{d}}=$ Gaya redam $(\mathrm{N}), \rho=$ Densitas fluida kerja $\left(\mathrm{kg} / \mathrm{m}^{3}\right)$, dan Koefisien discharge orifice $(\xi)=0.3$

\subsection{Respon Dinamis Sistem Suspensi Hydraulic Shock Absorber} dengan Variasi Frekuensi $(0.5 \mathrm{~Hz}-2 \mathrm{~Hz})$

Dilakukan simulasi dengan input sinusoidal sebanyak 4 kali menggunakan variasi frekuensi antara $0.5 \mathrm{~Hz}$ sampai $2 \mathrm{~Hz}$ dengan range $0.5 \mathrm{~Hz}$

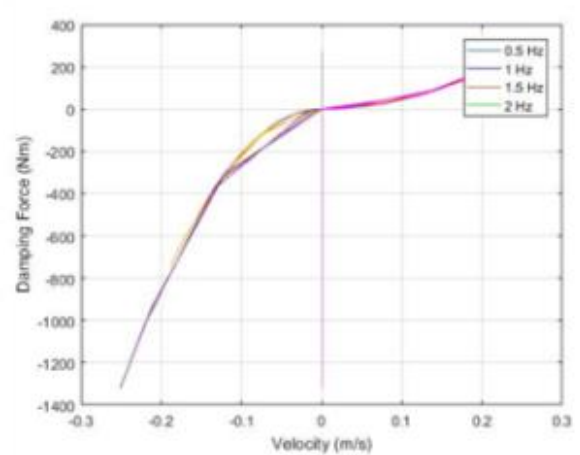

(a)

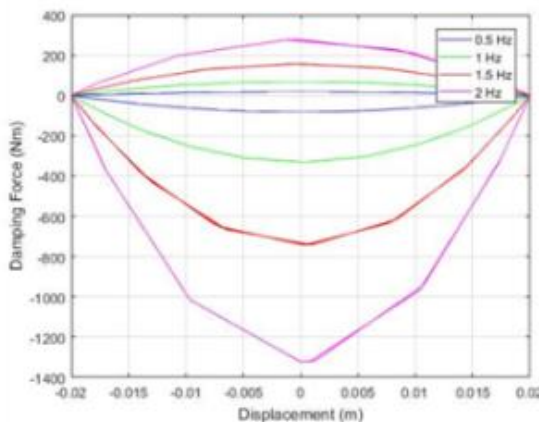

(b)

Gambar 5. Grafik respon kecepatan terhadap gaya redam (a) dan (b) grafik respon kecepatan terhadap gaya redam suspensi shock absoreber hidrolis pada frekuensi $0.5-2.5 \mathrm{~Hz}$

Pada grafik respon gaya redam terhadap perpindahan terlihat bahwa semakin bersar frekuensi, maka gaya redam yang dihasilkan semakin besar hal ini sudah sesuai teori. Berdasarkan rumus $\mathrm{Fd}=\mathrm{cx}$ dimana $\mathrm{Fd}$ merupakan gaya redam dan $\dot{\mathrm{x}}$ adalah kecepatan menunjukan nilai yang berbanding lurus. Kecepatan mempunyai rumus $\dot{\mathrm{x}}=f$. $\lambda$ dimana $\mathrm{f}$ frekuensi dan $\lambda$ adalah jarak tempuh. Rangkuman nilai gaya redam, perpindahan, kecepatan dan percepatan dapat dilihat di tabel 2

Tabel 2

Hasil Simulasi Silinder Hidrolis Pada Variasi Frekuensi 0.5-2 Hz

\begin{tabular}{lllll}
\hline \multirow{2}{*}{ Nilai Max } & \multicolumn{4}{c}{ Gaya Redam } \\
\cline { 2 - 5 } & $0,5 \mathrm{~Hz}$ & $1 \mathrm{~Hz}$ & $1,5 \mathrm{~Hz}$ & $2 \mathrm{~Hz}$ \\
\hline FD kompresi (N) & 82.7 & 330.7 & 734.8 & 1323.2 \\
FD ekspansi (N) & 17.278 & 69.112 & 155.5 & 276.45 \\
Velocity (m/s) & 0.063 & 0.126 & 0.189 & 0.251 \\
Displacement (m) & 0.02 & 0.02 & 0.02 & 0.02 \\
\hline
\end{tabular}

\subsection{Perumusan Seperempat Kendaraan pada Shock Absorber Hidrolis}

Pada pemodelan ini $\mathrm{m}_{\mathrm{p}}$ yaitu massa dari penumpang, $\mathrm{m}_{\mathrm{v}}$ yaitu massa body mobil, dan $\mathrm{m}_{\mathrm{t}}$ merupakan massa dari ban. $\mathrm{F}_{\mathrm{d}}$ merupakan gaya redam yang dihasilkan oleh sistem suspensi sedangkan Fk adalah gaya pegas dari vehicle mobil dan kt merupakan kekakuan dari ban.
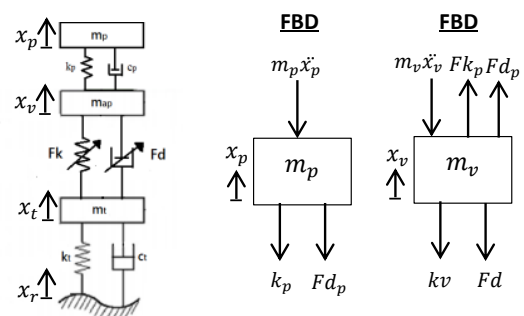

$\underline{F B D}$

Gambar 6. FBD untuk shock absorber hidrolis pada seperempat kendaraan

Persamaan matematis dari FBD 1 pada gambar 6 adalah sebagai berikut :

$-F k_{p}-F d_{p}-m_{p} \ddot{x_{p}}=0$

$k_{p}\left(x_{p}-x_{v}\right)+c_{p}\left(\dot{x}_{p}-\dot{x}_{v}\right)+m_{p} \ddot{x_{p}}=0$

$\ddot{x_{p}}=\frac{1}{m_{p}}\left[-k_{p}\left(x_{p}-x_{v}\right)-c_{p}\left(\dot{x}_{p}-\dot{x}_{v}\right)\right]$

Persamaan matematis dari FBD 2 pada gambar 6 adalah sebagai berikut :

$F k_{p}+F d_{p}-F k-F d-m_{v} \ddot{x_{v}}=0$

$k_{p}\left(x_{p}-x_{v}\right)+c_{p}\left(\dot{x}_{p}-\dot{x}_{v}\right)-k_{v}\left(x_{v}-x_{t}\right)-\frac{1}{2} p_{0} A\left[\left(\left(\frac{A}{\xi^{2} A_{0}}\right)^{2}-\right.\right.$

1) $\left.\left(\dot{x}_{v}-\dot{x}_{t}\right)^{2}\right]-m_{v} \ddot{x_{v}}=0$

$\ddot{x_{v}}=\frac{1}{m_{v}}\left[k_{p}\left(x_{p}-x_{v}\right)+c_{p}\left(\dot{x}_{p}-\dot{x}_{v}\right)-k_{v}\left(x_{v}-x_{t}\right)+\right.$

$\left.\frac{1}{2} p_{0} A\left[\left(\left(\frac{A}{\xi^{2} A_{0}}\right)^{2}-1\right)\left(\dot{x}_{v}-\dot{x}_{t}\right)^{2}\right]\right]$

Persamaan matematis dari FBD 3 pada gambar 6 adalah sebagai berikut :

$F k+F d-F k_{t}-F d_{t}-m_{t} \ddot{x}_{t}=0$

$k_{v}\left(x_{v}-x_{t}\right)+\frac{1}{2} p_{0} A\left[\left(\left(\frac{A}{\xi^{2} A_{0}}\right)^{2}-1\right)\left(\dot{x}_{v}-\dot{x}_{t}\right)^{2}\right]-k_{t}\left(x_{t}-x_{r}\right)-$

$c_{t}\left(\dot{x}_{t}-\dot{x}_{r}\right)-m_{t} \ddot{x}_{t}=0$

$\ddot{x}_{t}=\frac{1}{m_{t}}\left[k_{v}\left(x_{v}-x_{t}\right)+\frac{1}{2} p_{0} A\left[\left(\left(\frac{A}{\xi^{2} A_{0}}\right)^{2}-1\right)\left(\dot{x}_{v}-\dot{x}_{t}\right)^{2}\right]-\right.$

$\left.k_{t}\left(x_{t}-x_{r}\right)-c_{t}\left(\dot{x}_{t}-\dot{x}_{r}\right)\right]$

\subsection{Perumusan Gaya Redam pada Dual Flywheel}

Berikut merupakan pemodelan dinamis dari sistem dual flywheel:

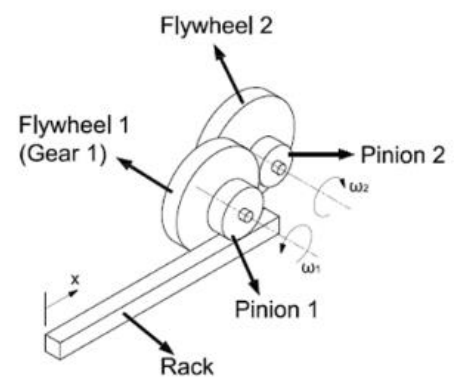

Gambar 7. Pemodelan dinamis dual flywheel

Tabel 3

Parameter sistem peredam dengan mekanisme Dual Flywheel

\begin{tabular}{ll}
\hline Parameter & Nilai \\
\hline Radius pinion & $30 \mathrm{~mm}$ \\
Radius flywheel & $40 \mathrm{~mm}$ \\
Ketebalan flywheel & $30 \mathrm{~mm}$ \\
$\rho$ Bruss casting & $\left.8400 \mathrm{~kg} / \mathrm{m}^{3}\right)$. \\
\hline
\end{tabular}

Sedangkan untuk pemodelan matematis dapat diturunkan menggunakan hukum II Newton. Sehingga didapatkan gaya redam untuk dual flywheel adalah sebagai berikut : 


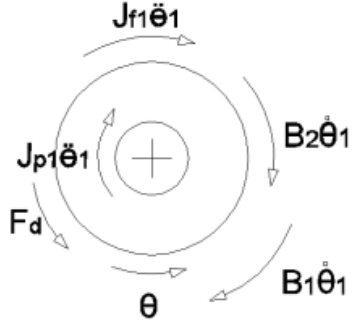

Ditinjau dari flywheel 1 dan pinion 1: $\oplus \sum M=0$

$\mathrm{F}_{d}=\left[\frac{1}{R_{f 1}}\left(\left(\mathrm{~J}_{f 1}-\mathrm{J}_{p 1}\right) \ddot{\theta}_{1}+\left(\mathrm{B}_{1}+\right.\right.\right.$ $\left.\left.\left.\mathrm{B}_{2}\right) \dot{\theta}_{1}\right)\right]$

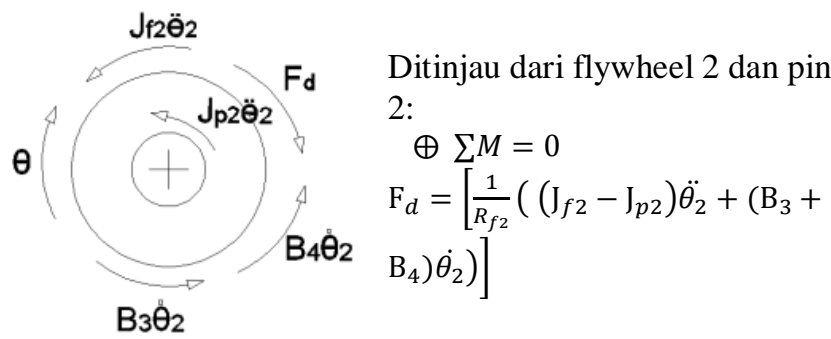

Dimana $\mathrm{J}$ adalah momen inersia polar, $\theta$ adalah perpindahan sudut, dan B adalah gaya gesek akibat bearing.

\subsection{Respon Dinamis Sistem Suspensi Dual Flywheel dengan}

Variasi Frekuensi $(0.5 \mathrm{~Hz}-2 \mathrm{~Hz})$

Berdasarkan tabel, dilakukan simulasi sebanyak 4 kali yang terdiri dari variasi input sinusoidal dengan frekuensi antara $0.5 \mathrm{~Hz}$ sampai $2 \mathrm{~Hz}$ dengan range $0.5 \mathrm{~Hz}$

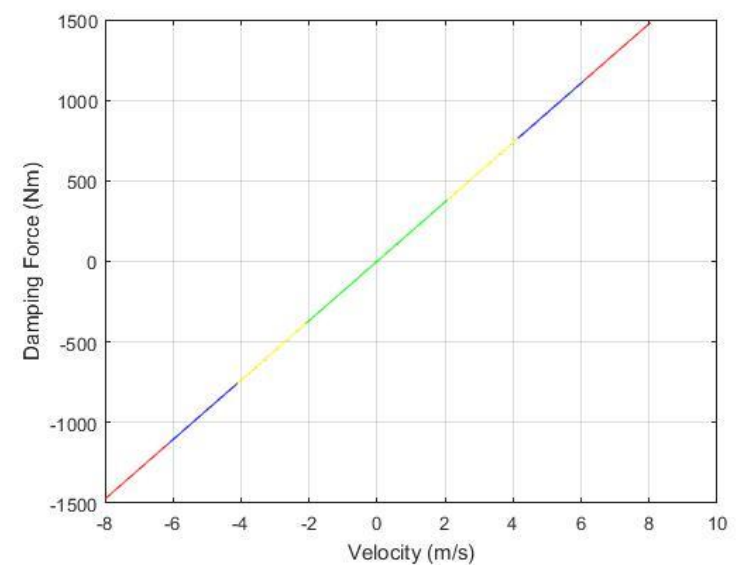

(a)

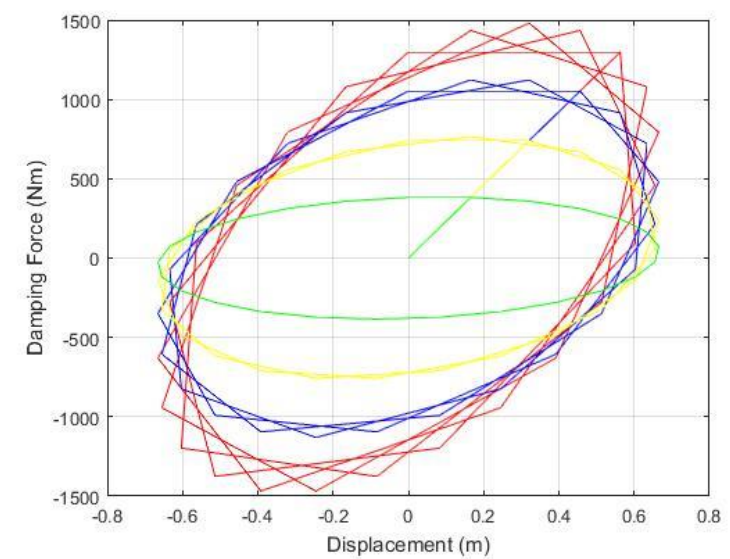

(b)

Gambar 8. Grafik respon kecepatan terhadap gaya redam (a) dan (b) grafik respon kecepatan terhadap gaya redam suspensi dual flywheel pada frekuensi $0.5-2.5 \mathrm{~Hz}$

Hasil simulasi dapat dilihat dari tabel 5.3.
Tabel 4

Hasil Simulasi Dual Flywheel Pada Variasi Frekuensi $0.5-2 \mathrm{~Hz}$

\begin{tabular}{cccccc}
\hline Besar nilai & & $0.5 \mathrm{~Hz}$ & $1 \mathrm{~Hz}$ & $1.5 \mathrm{~Hz}$ & $2 \mathrm{~Hz}$ \\
\hline Damping Force & Min & 395 & 777 & 1150.2 & 1469 \\
$(\mathrm{~N})$ & $\mathrm{Max}$ & 392 & 783 & 1151.0 & 1480 \\
$\begin{array}{c}\text { Velocity (m/s) } \\
\text { Displacement } \\
(\mathrm{m})\end{array}$ & Max & 2.07 & 4.14 & 6.087 & 8.03 \\
\hline
\end{tabular}

3.6 Perumusan Seperempat Kendaraan pada Dual Flywheel

Pada pemodelan ini $\mathrm{m}_{\mathrm{p}}$ yaitu massa dari penumpang, $\mathrm{m}_{\mathrm{v}}$ yaitu massa body mobil, dan $\mathrm{m}_{\mathrm{t}}$ merupakan massa dari ban. $\mathrm{F}_{\mathrm{d}}$ merupakan gaya redam yang dihasilkan oleh sistem suspensi sedangkan Fk adalah gaya pegas dari vehicle mobil yang akan digantikan oleh susunan layout baru yang digunakan layout dari susunan pegas dual flywheel.

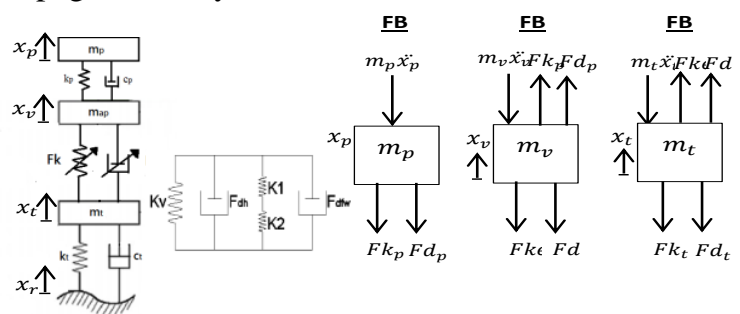

Gambar 9 FBD untuk dual flywheel pada seperempat kendaraan

Persamaan matematis dari FBD 1 pada gambar 8 adalah sebagai berikut :

$-F k_{p}-F d_{p}-m_{p} \ddot{x_{p}}=0$

$k_{p}\left(x_{p}-x_{v}\right)+c_{p}\left(\dot{x}_{p}-\dot{x}_{v}\right)+m_{p} \ddot{x_{p}}=0$

$\ddot{x_{p}}=\frac{1}{m_{p}}\left[-k_{p}\left(x_{p}-x_{v}\right)-c_{p}\left(\dot{x}_{p}-\dot{x}_{v}\right)\right]$

Persamaan matematis dari FBD 2 pada gambar 8 adalah sebagai berikut :

$F k_{p}+F d_{p}-F k_{e q}-F d-m_{v} \ddot{x}_{v}=0$

$k_{p}\left(x_{p}-x_{v}\right)+c_{p}\left(\dot{x}_{p}-\dot{x}_{v}\right)-k_{e q}\left(x_{v}-x_{t}\right)-\left\{\left[\frac{1}{R_{f 1}}\left(\left(\mathrm{~J}_{f 1}-\right.\right.\right.\right.$

$\left.\left.\left.\mathrm{J}_{p 1}\right) \ddot{\theta}_{1}+\left(\mathrm{B}_{1}+\mathrm{B}_{2}\right) \dot{\theta_{1}}\right)\right]-\left[\frac{1}{R_{f 2}}\left(\left(\mathrm{~J}_{f 2}-\mathrm{J}_{p 2}\right) \frac{\mathrm{R}_{\mathrm{p} 2} \mathrm{x} \ddot{\theta_{1}}}{\mathrm{R}_{\mathrm{F} 1}}+\left(\mathrm{B}_{3}+\right.\right.\right.$

$\left.\left.\left.\left.\mathrm{B}_{4}\right) \frac{\mathrm{R}_{\mathrm{p} 2} \mathrm{x} \dot{\theta_{1}}}{\mathrm{R}_{\mathrm{F} 1}}\right)\right]\right\}-m_{v} \ddot{x_{v}}=0$

Karena $x_{v}=\theta_{v} \mathrm{R}$ maka $\theta_{v}=\frac{x_{v}}{\mathrm{R}}, \dot{\theta}_{v}=\frac{\dot{x_{v}}}{\mathrm{R}}, \ddot{\theta_{1}}=\frac{\ddot{x_{v}}}{\mathrm{R}}$ Sehingga :

$\ddot{\mathrm{x}_{v}}=\frac{1}{m_{v}+\frac{1\left(\mathrm{I}_{f 1}-\mathrm{J}_{p 1}\right)_{1} \mathrm{R}_{\mathrm{p} 2}\left(\mathrm{I}_{f 2}-\mathrm{J} p 2\right)}{R_{f 1} \mathrm{R}_{\mathrm{F} 1} R_{P 2} \mathrm{R}_{\mathrm{F} 1} \mathrm{R}_{\mathrm{p} 2}}}\left[k_{p}\left(x_{p}-x_{v}\right)+c_{p}\left(\dot{x}_{p}-\dot{x}_{v}\right)-\right.$

$k_{e q}\left(x_{v}-x_{t}\right)-\left\{\left[-\frac{1}{R_{f 1}} \frac{\left(\mathrm{J}_{f 1}-\mathrm{J}_{p 1}\right)}{\mathrm{R}_{\mathrm{F} 1}} \ddot{\mathrm{x}}_{t}+\left(\frac{\left(\mathrm{B}_{1}+\mathrm{B}_{2}\right)}{\mathrm{R}_{\mathrm{F} 1}}\left(\dot{x_{v}}-\dot{x_{t}}\right)\right)\right]-\right.$

$\left.\left.\left[\frac{1}{R_{P 2}}\left(\frac{\mathrm{R}_{\mathrm{p} 2}}{\mathrm{R}_{\mathrm{F} 1}} \frac{\left(\mathrm{J}_{f 2}-\mathrm{J}_{p 2}\right)}{\mathrm{R}_{\mathrm{p} 2}} \ddot{\mathrm{x}}_{t}+\frac{\mathrm{R}_{\mathrm{p} 2}}{\mathrm{R}_{\mathrm{F} 1}} \frac{\left(\mathrm{B}_{3}+\mathrm{B}_{4}\right)}{\mathrm{R}_{\mathrm{p} 2}}\left(\dot{x}_{v}-\dot{x}_{t}\right)\right)\right]\right\}\right]$

Persamaan matematis dari FBD 3 pada gambar 8 adalah sebagai berikut :

$F k_{e q}+F d-F k_{t}-F d_{t}-m_{t} \ddot{x}_{t}=0$

$k_{e q}\left(x_{v}-x_{t}\right)+\left\{\left[\frac{1}{R_{f 1}}\left(\frac{\left(\mathrm{J}_{f 1}-\mathrm{J}_{p 1}\right)}{\mathrm{R}_{\mathrm{F} 1}}\left(\ddot{\mathrm{x}}_{v}-\ddot{\mathrm{x}}_{t}\right)+\frac{\left(\mathrm{B}_{1}+\mathrm{B}_{2}\right)}{\mathrm{R}_{\mathrm{F} 1}}\left(\dot{x_{v}}-\dot{x_{t}}\right)\right)\right]-\right.$

$\left.\left[\frac{1}{R_{P 2}}\left(\frac{\mathrm{R}_{\mathrm{p} 2}}{\mathrm{R}_{\mathrm{F} 1}} \frac{\left(\mathrm{J}_{f 2}-\mathrm{J}_{p 2}\right)}{\mathrm{R}_{\mathrm{p} 2}}\left(\ddot{\mathrm{x}}_{v}-\ddot{\mathrm{x}}_{t}\right)+\frac{\mathrm{R}_{\mathrm{p} 2}}{\mathrm{R}_{\mathrm{F} 1}} \frac{\left(\mathrm{B}_{3}+\mathrm{B}_{4}\right)}{\mathrm{R}_{\mathrm{p} 2}}\left(\dot{x}_{v}-\dot{x_{t}}\right)\right)\right]\right\}-$

$k_{t}\left(x_{t}-x_{r}\right)-c_{t}\left(\dot{x}_{t}-\dot{x}_{r}\right)-m_{t} \ddot{x}_{t}=0$

$\ddot{x_{t}}=\frac{1}{m_{t}-\frac{1\left(\mathrm{~J}_{f 1}-\mathrm{J}_{p 1}\right)}{R_{f 1} \mathrm{R}_{\mathrm{F} 1}}+\frac{1\left(\mathrm{~J}_{f 2}-\mathrm{J} p 2\right)}{R_{P 2}} \mathrm{R}_{\mathrm{p} 2}}\left[k_{e q}\left(x_{v}-x_{t}\right)+\left\{\left[\frac{1}{R_{f 1}}\left(\frac{\left(\mathrm{J}_{f 1}-\mathrm{J}_{p 1}\right)}{\mathrm{R}_{\mathrm{F} 1}} \ddot{x}_{v}+\right.\right.\right.\right.$

$\left.\left.\frac{\left(\mathrm{B}_{1}+\mathrm{B}_{2}\right)}{\mathrm{R}_{\mathrm{F} 1}}\left(\dot{x_{v}}-\dot{x_{t}}\right)\right)\right]-\left[\frac{1}{R_{P 2}}\left(-\frac{\mathrm{R}_{\mathrm{p} 2}}{\mathrm{R}_{\mathrm{F} 1}} \frac{\left(\mathrm{J}_{f 2}-\mathrm{J}_{p 2}\right)}{\mathrm{R}_{\mathrm{p} 2}} \ddot{\mathrm{x}_{v}}+\frac{\mathrm{R}_{\mathrm{p} 2}}{\mathrm{R}_{\mathrm{F} 1}} \frac{\left(\mathrm{B}_{3}+\mathrm{B}_{4}\right)}{\mathrm{R}_{\mathrm{p} 2}}\left(\dot{x}_{v}-\right.\right.\right.$

$\left.\left.\left.\left.\left.\dot{x}_{t}\right)\right)\right]\right\}-k_{t}\left(x_{t}-x_{r}\right)-c_{t}\left(\dot{x}_{t}-\dot{x}_{r}\right)\right]$ 
3.7 Perbandingan Respon Dinamis Penumpang dari Sistem Seperempat Kendaraan dengan Suspensi Shock Absorber Hidrolis dengan Suspensi Dual Flywheel Akibat Input Bump yang Dimodifikasi

- Input bump dengan severity parameter $(\gamma)=1$

Dari pemodelan pada penumpang dengan input pada blok diagram dengan $(\gamma)=1$ didaptkan hasil berikut:

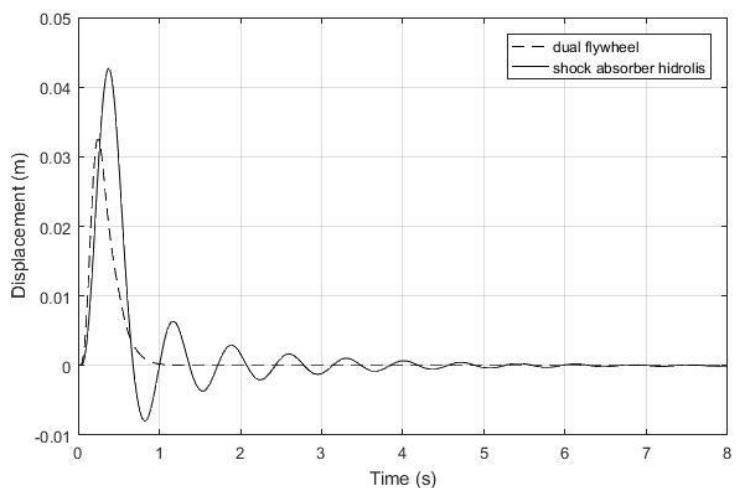

(a)

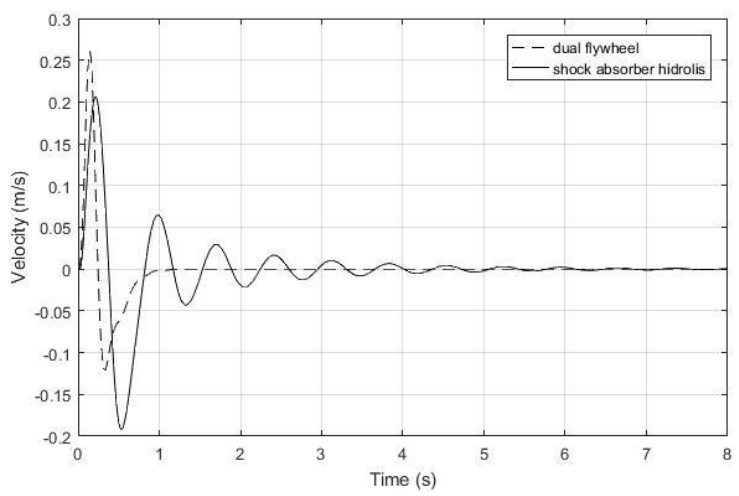

(b)

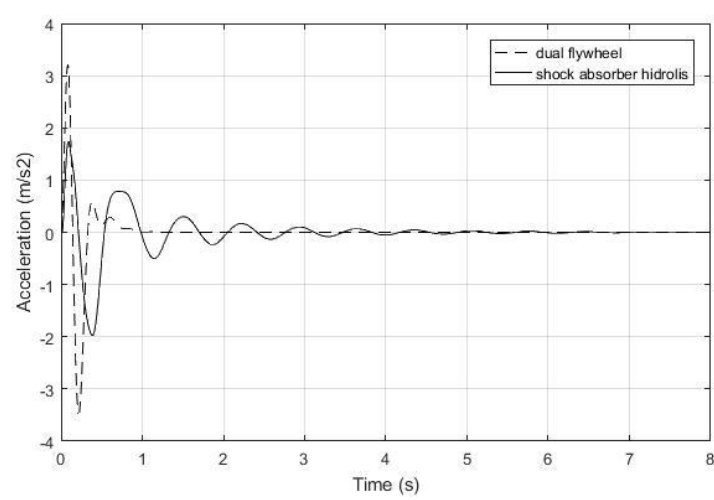

(c)

Gambar 10. Grafik perbandingan respon (a) perpindahan, (b) kecepatan, (c) percepatan pada penumpang suspensi yang menggunakan shock absorber hidrolis dan dual flywheel terhadap waktu dengan input bump modified $(\gamma=1)$

Tabel 5

Nilai perpindahan, kecepatan, dan percepatan maksimum pada seperempat kendaraan mobil yang menggunakan shock absorber hidrolis dan dual flywheel terhadap waktu dengan input bump modified $(\gamma=1)$

\begin{tabular}{lcccc}
\hline Jenis suspensi & $\begin{array}{c}\mathrm{x} \text { maks } \\
(\mathrm{m})\end{array}$ & $\begin{array}{c}\mathrm{v} \text { maks } \\
(\mathrm{m} / \mathrm{s})\end{array}$ & $\begin{array}{c}\text { a maks } \\
\left(\mathrm{m} / \mathrm{s}^{2}\right)\end{array}$ & $\begin{array}{c}\text { Settling time } \\
(\mathrm{s})\end{array}$ \\
\hline $\begin{array}{l}\text { Shock absorber } \\
\text { lidrolis }\end{array}$ & 0.0425 & 0.205 & 1.7345 & 7 \\
$\quad$ Dual flywheel & 0.0326 & 0.2598 & 3.2074 & 1 \\
\hline
\end{tabular}

\subsection{Input Sinusoidal Pada Pemodelan Untuk Penumpang}

Pemodelan dilakukan dengan memberi input pada blok diagram dengan severity parameter sebesar 30 .

- Input kecepatan $30 \mathrm{~km} / \mathrm{jam}$

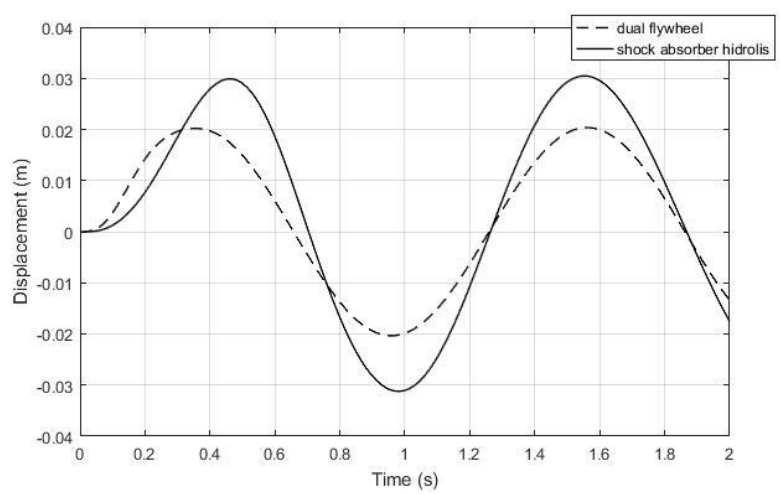

(a)

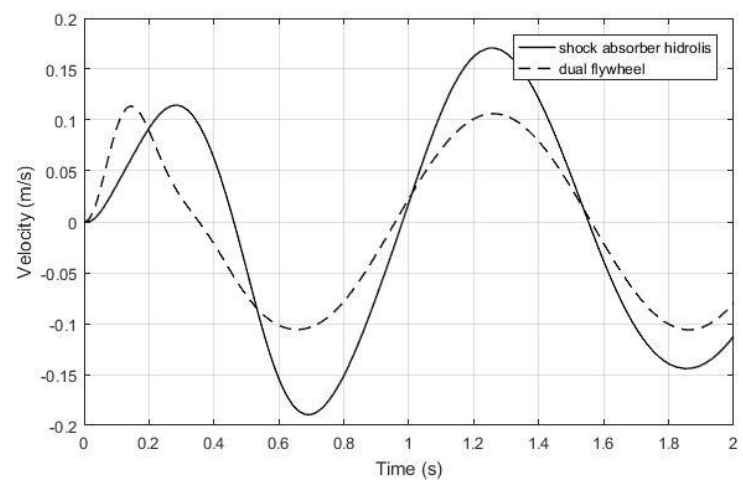

(b)

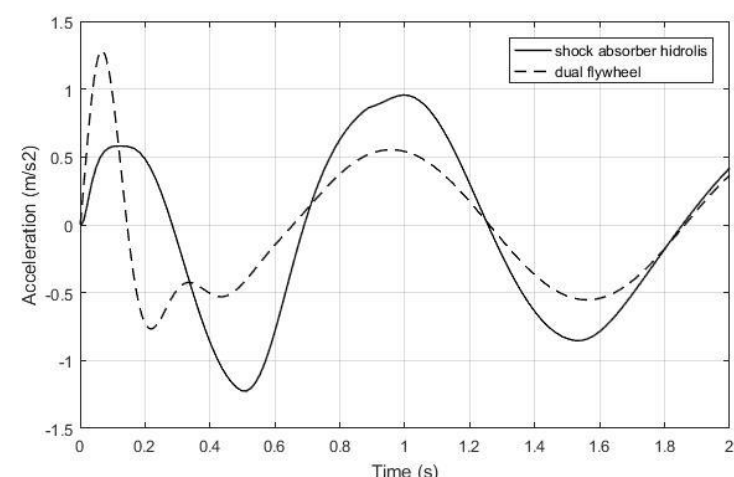

(c)

Gambar 11 Respon penumpang kendaraan akibat input sinusoidal varias kecepatan kendaraan terhadap (a) Perpindahan (b) Kecepatan (c) Percepatan

Tabel 8

Nilai perpindahan, kecepatan, dan percepatan maksimum pada penumpang seperempat kendaraan mobil terhadap waktu dengan input sinusoidal ( $\mathrm{v}=30$

\begin{tabular}{cccc}
\multicolumn{4}{c}{$\mathrm{km} / \mathrm{h})$} \\
\hline Parameter & $\begin{array}{c}\mathrm{x} \text { maks } \\
(\mathrm{m})\end{array}$ & $\begin{array}{c}\mathrm{v} \text { maks } \\
(\mathrm{m} / \mathrm{s})\end{array}$ & $\begin{array}{c}\mathrm{a} \text { maks } \\
\left(\mathrm{m} / \mathrm{s}^{2}\right)\end{array}$ \\
\hline $\begin{array}{c}\text { Shock absorber } \\
\text { Hidrolis }\end{array}$ & 0.031 & 0.1761 & 0.956 \\
Dual Flywheel & 0.0204 & 0.1135 & 1.2815 \\
\hline
\end{tabular}

\subsection{Displacement Transmibility}

Displacement transmibility merupakan perpindahan bodi kendaraan terhadap kecepatan kendaraan. Dari kecepatan tersebut, akan diperoleh nilai frekuensi $\mathrm{f}=v / \lambda$ untuk dijadikan inputan berupa sinusoidal. Karena displacement transmibility merupakan perpindahan bodi kendaraan terhadap kecepatan kendaraan maka nilai $\mathrm{x}$ rms terlebih dahulu dibagi dengan nilai amplitudo yang digunakan yaitu 0.02 . 
Perbandingan displacement transmissibility antara sistem seperempat kendaraan dengan shock sbsorber hidrolis dan dual flywheel dinyatakan pada grafik perpindahan berikut:

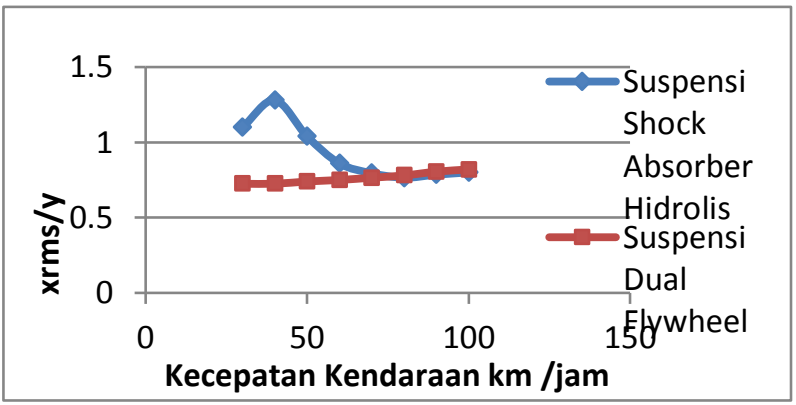

Gambar 12 Grafik Perpindahan penumpang Terhadap Kecepatan Kendaraan

\subsection{Percepatan RMS bodi kendaraan terhadap kecepatan kendaraan}

Gambar di bawah ini menunjukkan grafik respon percepatan RMS (Root Mean Square) terhadap kecepatan yang dikonversikan terhadap frekuensi dengan rumus $\mathrm{f}=\nu / \lambda$ untuk dijadikan inputan berupa sinusoidal. Dari grafik ini, dapat dilihat berapa lama ketahanan pengendara saat berkendara menurut ISO 2631 untuk setiap frekuensi kendaraan [3].

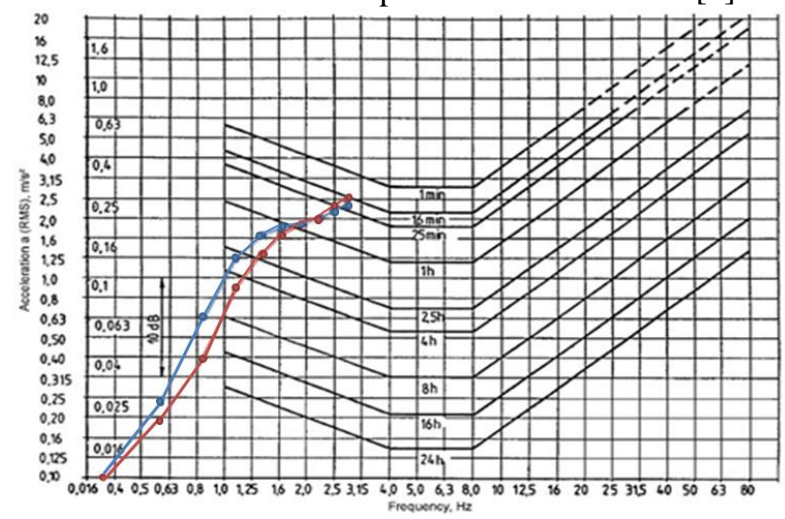

Gambar 13 Ketahanan pengemudi terhadap percepatan body kendaraan

Nilai percepatan RMS dari mobil dengan suspensi shock absorber hidrolis mempunyai karakteristik lebih besar dibandingkan dengan suspense dual flywheel pada kecepatan 10-80 km/jam. Sedangkan saat kecepatan tinggi yaitu 90-100 $\mathrm{km} / \mathrm{jam}$ nilai displacement transmissibility dari flywheel akan lebih besar dibandingkan suspensi shock absorber hidrolis. Nilai ketahanan tubuh penumpang terhadap getaran pada suspense dual flywheel untuk kecepatan 10-80 km/jam lebih aman daripada suspense shock absorber hidrolis

\section{KESIMPULAN}

\subsection{Kesimpulan}

Berdasarkan hasil simulasi dan analisa maka dapat disimpulkan bahwa:

1. Gaya redam maksimum pada shock absorber hidrolis didapatkan dari proses ekspansi maupun kompresi. Nilai gaya redam saat saat proses kompresi menunjukkan nilai yang lebih besar dibandingkan dengan saat ekspansi.

2. Dengan menggunakan input bump yang telah dimodifikasi, penumpang dengan penggunaan mobil suspensi dual flywheel lebih cepat mengalami steady state jika dibandingkan dengan mobil seperempat kendaraan yang menggunakan suspensi shock absorber hidrolis

3. Suspensi dual flywheel pada kecepatan $10-80 \mathrm{~km} / \mathrm{jam}$ mempunyai nilai a RMS lebih rendah jika dibandingkan dengan shock absorber hidrolis. Hal ini menunjukkan bahwa nilai ketahanan tubuh penumpang terhadap getaran pada kendaraan dengan suspensi dual flywheel untuk kecepatan 10-80 km/jam lebih aman daripada suspense shock absorber hidrolis.

\subsection{Saran}

Berdasarkan penelitian yang telah dilakukan, saran untuk pengembangan dalam penelitian selanjutnya adalah:

1. Harus dilakukan uji eksperimen untuk memvalidasi simulasi dari hasil matematis pemodelan pada sistem suspensi dual flywheel pada tiap-tiap variasi.

\section{DAFTAR PUSTAKA}

[1] Blundell, Michael and Harty, Damian. 2015. Types of suspension and drive. : Elsevier Ltd.

[2] Fox dan McDonald's. 2011. Introduction to Fluid Mechanics Eighth Edition. Amerika: John Wiley \& Sons, Inc.

[3] ISO: Guide for The Evaluation of Human Exposure to Whole-Body Vibration. 1997. International Standart 2631. International Organization for Standardization. 